\title{
Top Management Team Demographic Diversities, Generic Strategy and Firm Performance in Marketing Social Research Association (MSRA) in Kenya
}

\author{
Tecle, H. Yohannes ${ }^{1} \&$ Aloys B. Ayako ${ }^{1}$ \\ ${ }^{1}$ Faculty of Commerce, the Catholic University of Easter Africa, P.O. Box 62157-00200, Nairobi-Kenya. \\ Correspondence: Aloys B. Ayako, Faculty of Commerce, the Catholic University of Easter Africa, P. O. Box \\ 62157-00200, Nairobi, Kenya.
}

Received: March 18, 2016

Accepted: April 27, 2016

Available online: May 3, 2016

doi:10.11114/afa.v2i2.1586

URL: http://dx.doi.org/10.11114/afa.v2i2.1586

\begin{abstract}
This study investigated the relationship between Top Management Team (TMT) demographic diversities and firm performance using generic strategies as intervening variable in the Marketing and Social Research Association (MSRA) firms in Kenya. First, the relationship between TMT characteristics diversities and generic strategy was analyzed. Second, the link between generic strategy and firm performance was estimated. Mixed methods research design was used to critically investigate the relationship between the latent exogenous and endogenous variables of this study. The mixed research design used in this study was triangulation design, which was mainly transformation design model. The data were analyzed using structural equation modeling analysis, using IBM SPSS AMOS version 21. The study found out that the homogenous demographic diversities among the top management team members had statistically significant effect on cost leadership strategy $(p=0.012)$. Besides, cost leadership strategy showed a statistically significant positive relationship on firm performance $(p=0.005)$. The findings of this study implied that organizations need to know and develop the best composition of top management team based on their demographic diversities in relation to the environment. Besides, the organizations need to empower the TMT members using monetary and nonmonetary incentives to further improve performance. Last but not least, the compositions of TMT in marketing research firms need to embrace gender diversity.
\end{abstract}

Keywords: Top management team, Demographic characteristics, Generic strategy, Performance

\section{Introduction}

Investigation on the characteristics of Top Management Teams (TMTs) and their impact on firm performance has attracted considerable research interest (Kakabadse, Kakabadse, \& Barrat, 2006; Kroll, Walter \& Le, 2007). Besides, Auden, Shackman, and Onken (2006) further suggest that determination of the best composition of TMT is an appropriate unit of study for a research due to its impact on firm performance. Moreover, Marimuthu and Kolandaisamy (2009) opine that TMT does important corporate decisions and set strategic directions for the organization. They further contend that TMT is a key component that affects firm performance. Likewise, the Upper Echelon (UE) theory developed by Hambrick and Mason (1984) posit that firm performance is the reflection of TMT. That is why, the effectiveness of TMT and its impact on firm performance is always a central focus in most strategic management research (Goll, Sambharya, \& Tucci, 2001).

However, the empirical results from the previous studies show inconsistent conclusions (Chen, Ge, \& Song 2010; Amy, Michael, \& Michael, 2003). The UE theory suggests that the demographic characteristics of TMT affect the choice of strategy (Hambrick \& Mason, 1984). The study by Daniel, Tanja, and Utz (2007) supports the assumption of EU theory that TMT strongly influence a firm's strategic choice or decision-making. However, EU theory focuses on grand strategies, but it does not emphasize on business and functional strategies. As a result, Carpenter (2002) suggests that the inconsistent relationship between characteristics of TMT and firm performance could be due to the omission of business strategy as an intervening variable. Furthermore, Irene, Nancy, and Abdul (2008) and Porter (1980) suggest that the business strategies could be generic strategies. 


\subsection{Problem Statement}

From the above discussion, the empirical researches assessing the impact of TMT demographic characteristics on firm performance show inconsistent results. Besides, scholars remained divided which managerial characteristics or TMT attributes are essential for firm performance (Mason \& Gregory, 2006). Several methods have been proposed by scholars to solve the inconsistent results. These are business strategy as intervening variable (Carpenter, 2002), adequate performance measures (Nielsen, 2010) and applying the right research methodology (Hooper et al., 2008).

Business strategy is considered as an intervening variable as suggested by Carpenter (2002). This is because the UE theory considers grand strategy as an intervening variable (Hambrick \& Mason, 1984) while ignoring business strategy as an intervening variable. Porter (1980) and Kaplan (2010) posit that business strategies are the main sources of competitive advantage and they enable an organization to achieve long-term objectives.

Today, traditionally financially oriented systems of performance measures no longer work alone (Margarita, 2008). Instead, both monetary and non-monetary measures of performance are becoming more effective (Kaplan, 2010). Hence, this study used both tangible and intangible assets to measure firm performance to address the research objectives. The balanced scorecard and human resource scorecard were incorporated with the UE theory to consider both monetary and non-monetary performance measures.

Furthermore, proper selection of research methodology is a central part of any research study. While inappropriate research design and analysis method cannot address the research objectives it may lead to incorrect conclusions. Consequently, such invalid methods may result inconsistent empirical results. Inconsistent findings of the previous studies could be attributed to the use of inappropriate research methodology. This is because most of the previous studies have used simple and multiple regression analysis while the dependent variable has more than one indicator. When the dependent variable has many indicators, the best analysis method is Structural Equation Modeling (SEM). Besides, SEM allows measurement errors, structural disturbances, covariance and direct and indirect effects simultaneously. These make SEM more sophisticated analysis than the multivariate regression model.

\section{Research Questions}

The primary objective of this study was to identify the impact of TMT attributes on firm performance using generic strategies as intervening variable. This was achieved through the following research questions:

a) To what extent do TMT demographic diversities affect generic strategic choice in Marketing Social Research Association (MSRA) firms in Kenya?

b) What is the relationship between the generic strategic choice and performance of MSRA firms in Kenya ?

\subsection{Hypothesis of the Study}

Hypothesis is a proposed explanation for a phenomenon. In other words, it is a tentative statement about the relationship between or among the variables. The null hypotheses among the demographic characteristics diversities of TMT, generic strategies and firm performance are stated below.

$\mathrm{H}_{01}$ : Demographic characteristics diversities in TMT have statistically insignificant effect on generic strategies.

$\mathrm{H}_{02}$ : Generic strategies have statistically insignificant effect on firm performance.

\subsection{Literature Review}

\subsubsection{Effects of TMT Demographic Characteristics on Business Strategic Choice}

The study by Irene et al. (2008) on the relationship between education level and differentiation strategy using multiple regression analysis in US airline industry showed a significant positive relationship. Likewise, the results of Thomas et al. (2004) confirmed a positive relationship between CEO education level and differentiation strategy but a negative relationship between education level and cost leadership strategy.

Tihanyi et al. (2000) and Wiersema and Bantel (1992) also found that higher education level had a positive relationship to strategic change. Likewise, Camelo et al. (2005) and Herrmann and Datta (2005) confirmed a positive association between a high educational level with innovation and strategic change. Hence, managers with high educational level are more creative, risk-takers, innovative, flexible and faster information analyzers (Arpita, 2014). Herrmann and Datta (2005) further opined that TMT with higher average education level develop greater tolerance of ambiguity, are more receptive to ideas, and possess a base of knowledge and competences necessary for seeking new opportunities and evaluating numerous options. This implies that TMT with high level of education may apply differentiation strategy to create a unique value in the mind of the customers and to gain competitive edge within the industry.

The previous scholars suggested that educational background influences strategic decision-making process (Hitt \& Tyler, 1991). Tihanyi et al. (2000) and Finkelstein (1992) argued that TMT with diverse educational background base may be 
better equipped to deal with complex environments. Likewise, Wiersema and Bantel (1992) found out that functional background significantly influenced executives' analytical and decision-making perspectives. However, there was not enough evidence about the relationship between educational background and business strategic choice.

Thomas et al. (2004) studied the relationship between age and generic strategy in an electronics industry. Their results revealed that younger TMTs are positively related to differentiation strategy, whereas older managers are associated with cost leadership strategy. Besides, the findings of Irene et al. (2008) showed a statistically significant relationship between younger managers and differentiation strategy. They argued that younger managers have less experience to rely on and are therefore more likely to innovate. Phani et al. (2012) further contended that older managers may be risk averse while younger managers may be more willing to pursue risky strategies like differentiation strategy.

Heng-Yih and Chia-Wen (2011) found that flexibility may decrease with age while rigidity and resistance to change increase with age. Hence, young managers are more flexible and less resistant to change and they may bring more current knowledge to the organization. Dimitrios et al. (2008) further posit that older managers have less physical, less mental stamina, low ability to grasp new ideas, and less able to learn new behaviours. These limitations of older manager may confine them to concentrate on cost leadership strategy rather than on differentiation strategy.

The most intriguing question in UE studies is the relationship between top managers' tenure and strategy (Hambrick, 2007). However, there is inadequate research done on the association between TMT tenure and generic strategic choice. Simeon (2001) studied the relationship between TMT tenure and business strategy in Japanese firms using regression analysis and analysis of variance. The business strategy was measured by internationalization, diversification and specialization. The result showed that TMT tenure has insignificant impact on business strategic choice.

Smith and Tushman (2005) posited that TMT with longer tenure may suffer from myopic vision, which does not result in strategic change (Wiersema and Bantel, 1992) or an inverse relationship between tenure and strategic change (Finkelstein \& Hambrick, 1990). Besides, Geletkanycz and Black (2001) found out that there is a negative relationship between longer functional diversity of TMT and commitment to strategic change. Carpenter (2002) also contended that TMT with diverse experiences will be better able to manage complex environment compare to homogeneous TMT.

Therefore, heterogeneous experience may bring various knowledge, abilities, and skills that can make the TMT members to be more flexible, creative and innovative. These attributes may help the strategic decision makers to understand the environment easily and to develop the best strategy to achieve the goals and objectives of the organization.

Last but not least, there is insufficient literature about top management female proportion and business strategic choice. However, gender diverse workforce may bring multiple source of information, variety of abilities to serve diverse customer base, and it attract and retain talented women. Likewise, Stephen et al. (2012) opine that women are both proactive and reactive, implying need to evaluate the impact of gender diversity on strategic choice.

In summary, there is limited research on the relationship between TMT demographic attributes diversity and generic strategic choice while it is central for the success of organization (Carpenter, 2002). Besides, the empirical results showed mixed results. This could be attributed to demographic characteristics diversities in TMT members, which may bring different task relevant capabilities, flexibility with the environment, creativity and innovation, information processing capacity, and risk taking behavior among others which may lead to different strategic choice.

\subsubsection{Effects of Generic Strategies on Firm Performance}

Thomas and William (2004) studied the impact of generic strategies on firm performance in the banking industry. They categorized the generic strategies as cost leadership, broad differentiation, customer service differentiation, and focus strategies. Among these strategic types, banks that follow a cost leadership strategy were found to perform better than banks that used the other generic strategies including stuck-in-the-middle strategy. Their findings are supported by Kumar et al. (1997) that a cost leadership strategy is the best route to superior performance in a hospital.

Power and Hahn (2004) also studied the influence of generic strategies on firm performance in banking industry. They divided the banks into five clusters based on the type of strategy they used. The strategies they used include differentiation, cost, stuck-in-the-middle, focus, and customer differentiation strategies. Their result showed that firms employing one of the generic strategies perform better in term of ROA than stuck-in-the-middle strategy. Their findings were consistent with those of Porter (1980). Kim et al. (2004), on the other hand, confirmed that firms adopting stuck-in-the- middle strategy are the highest performer in online mall while firms employing cost leadership strategy were the lowest performer.

Dess and Devis (1984) examined generic strategies and firm performance. They classified the strategies as cost leadership, differentiation, focus, and stuck-in-the- middle. The focus strategy revealed the highest sales growth and followed by cost leadership, differentiation, and stuck in the middle. The highest return was confirmed by the cost 
leadership and the lowest was evident in the focus strategy. Hlavacka et al. (2001) investigated the impact of generic strategies on performance in Slovak hospitals. They categorized the hospitals into four clusters based on the such a generic strategies as focus cost leadership, stuck-in-the- middle, wait and see, and cost leadership. Their result showed that stuck-in-the- middle strategy faired the best in improving firm performance.

Additionally, Michael (2010) studied the relationship between business level strategy and firm performance using environmental dynamism and hostility as moderators. His results indicated that, in stable environments, a cost-leadership strategy enhanced performance while in high hostile environments a differentiation strategy led to better performance. However, the study by Irene et al. (2008) in the US airline industry showed that a differentiation strategy is associated with better firm performance under regulation while cost leadership strategy is not correlated with performance either under regulated or deregulated environment.

However, Dushyantha (2008) found out that cost leadership and differentiation strategies significantly affect firm performance in small and middle enterprises in Japan. Rajiv et al. (2014) also argue that both cost leadership and differentiation strategies have positive impact on contemporaneous performance. They further argued that differentiation strategy allows a firm to sustain its current performance in the future to a greater extent than cost leadership strategy. Nandakumar et al. (2010) also found that the cost-leadership and differentiation strategies were not strongly correlated with the financial performance measures, indicating the limitations of Porter's generic strategies.

From the findings of past studies, business strategies have a profound influence on firm performance differences. Sujith et al. (2012) argue that firms' performance differences could accrue from knowledge brokering capability of TMT. Knowledge brokering has been defined as systematic approaches to seek extended ideas from people in a variety of industries, disciplines, and contexts and then combining the resulting lesson in a new way (Davidson \& Billington, 2010). On the other hand, Young (1999) argues that firm performance differences could be due to the difference in the understanding of the market structure which is a key determinant of the successful implementation of a differentiation or cost leadership strategy.

Furthermore, Bharadwaj et al. (1993) cited in Sujith et al. (2012) suggest that the firm performance differences could be explained by the development of particular resources and capabilities that the firm possesses that are not available in the competitors. Likewise, Thomas and William (2004) suggested that the ability to impact a cost leadership, differentiation, or focus strategies is dependent on firm's ability to develop specific set of competitive methods. They further posit that this will be the basis for achieving above average industry performance.

However, the impact of generic strategies on firm performance could be affected by the environment in which the firms operate, by type of organization, product life cycle, functional strategic alignment with generic strategies, and by the behavior of the customers among others (Michael, 2010; Pearson \& Richard, 2009; Boselie, 2010; Miller, 1992).

\section{Methodology}

This study used mixed methods research design to find out the relationship among the TMT demographic diversities, generic strategies and firm performance in Marketing and Social Research Association (MSRA) firms in Kenya. The data was collected using a questionnaire and interview guide and initially analyzed using heterogeneity index, coefficient of variance and confirmatory factor analysis. Finally, structural equation modeling analysis was used to find out the relationship between the latent variables of this study.

\subsection{Sampling}

The data for this study were collected semiannually for 12 years from 2003-2014. The reason why the data were collected semiannually was to have adequate sample size (cases) for SEM analysis. A useful rule of thumb concerning the relationship between sample size and model parameters has empirical support as N:q rule (Jackson, 2003). This rule is applicable when the estimation method is maximum likelihood. In maximum likelihood estimation, Jackson (2003) suggested that researchers think about minimum sample size in terms of the ratio of cases $(\mathrm{N})$ to the number of model parameters that require statistical estimates (q). An ideal sample size-to-parameters ratio would be 20:1. For example, if a total of $\mathrm{q}=10$ model parameters require statistical estimates, then an ideal minimum sample size would be $20 \times 10$, or $\mathrm{N}=200$. Less ideal would be an $\mathrm{N}$ : q ratio of 10:1. As the $\mathrm{N}: \mathrm{q}$ ratio decreases below 10:1 (e.g. 5:1), so does the trustworthiness of the results.

However, Kline (2011) stated that smaller sample sizes are required when the distributions of continuous outcome variables are normal in shape and their association with one another is linear. The sample size for the SEM was 216 $(24 \times 9)$ cases and the model parameters require statistical estimation was 31 . This implies that the ratio of sample size-to-parameters was 7:1. Therefore, the sample size was adequate to analyze using SEM.

\subsection{Validity of Research Instruments}

Validity is the accuracy and meaningfulness of inference, which are based on the research results. Zikmund et al. (2010) 
defined validity as the accuracy of a measure or the extent to which a score truthfully represents a concept. In other words, validity is the degree to which results obtained from the analysis of the data actually represent the phenomenon under study. The validity of this study was measured using content validity, construct validity, convergent validity and discriminant validity.

\subsection{Data Analysis Procedure}

In this study, data analysis was done using SEM. SEM analysis is the advanced form of multiple regressions and it is the best analyses that can address the research objectives under study. Hooper et al. (2008) posit that SEM has become one of the techniques of choice of data analysis for studies across disciplines and increasingly is a must for studies in social sciences.

The latent exogenous variable was TMT demographic diversity while the latent endogenous variables were generic strategies and firm performance. Hence, to undertake the SEM analysis, the indicators of the three latent variables were measured as discussed below.

\subsection{Top Management Team Demographic Diversity}

The TMT demographic characteristics were measured using TMT members' educational level diversity, educational background diversity, experience diversity, age diversity and female proportion in TMT. However, the gender diversity within TMT members of MSRA was insignificant. It was therefore omitted from the analysis of this study.

TMT members' educational background was categorized into twelve areas of specializations. These were strategic management, human resource management, economics, accounting and finance, marketing, entrepreneurship, law, engineering, math, econometrics, research and planning, and others. Similarly, educational level was categorized as $\mathrm{PhD}$, master degree, bachelor degree and others. Then, Blau's (1977) heterogeneity index was used to calculate diversities in educational level and educational background. This index is frequently used diversity measure for categorical variables and it takes values form 0 to 1 . High value indicates more heterogeneous TMT members while low value indicates homogenous TMT members. The formula of heterogeneity index developed by Blau (1977) is given below.

$$
\mathbf{D}=\mathbf{1}-\left(\sum \mathbf{P}^{\mathbf{2}}\right)
$$

Where; $\mathbf{D}$ represents diversity, $\mathbf{P}$ represents the proportion of group members in a given category, and ì represents the number of different categories of the features across all groups.

The diversities of age and tenure in TMT members were calculated using the coefficient of variance. Coefficient of variance is the standard deviation divided by the mean. Allison (1978) states that being a scale invariant measure, this coefficient is preferable to the standard deviation or variance for interval scaled variables. The larger the coefficient of variance, the greater is the diversity within the team while the small the coefficient of variance, the smaller will be the diversity within TMT members. The interpretation of diversity is the same as heterogeneity index.

\subsubsection{Generic Strategy}

The generic strategies were measured as either differentiation or cost leadership strategies. Porter (1980) suggests that a company must focus on one of the two generic strategies if it hopes to gain above average returns. The findings of Dushyantha (2008), Allen and Helms (2006), Thomas and William (2004), Power and Hahn (2004) and Nayyar (1993) support the view that firms employing one of the generics strategies perform better than firms which employ the stuck -in -the middle strategy. This is because firms applying this strategy avoid customers who demand low cost products and also lose high margin products demanders, leading to lower market share. The way out for these firms is to take steps to pursue one of the three generic strategies based on the capabilities and limitations of the firm concerned. That is why, this study decided to focus on differentiation and cost leadership strategies regardless of the market scope.

The business strategic choice of each firm was determined by regressing latent endogenous variable (generic strategy) on the latent exogenous variable (TMT demographic diversities) in the SEM. The strategic choice indicators are; maintenance expenses (MTE), advertisement expense (ADE), software purchase expenses (SPE), society support expenses (SSE) and salary increment (SI). Therefore, this study assumed that when diversities increases and cost increases or when diversities decreases and cost increases at 5\% level of significance, it means that the strategy is differentiation. That is, the higher of the expenses on the five strategic indicators, the greater the emphasis on a differentiation strategy to achieve the end result. In other words, the focus is on quality service regardless of much concentration on costs.

However, when diversity in TMT characteristics increases or decreases leads to cost reduction at 5\% level of significance, the strategy of the firm is cost leadership strategy. That is, the smaller the expenses, the greater the emphasis on a low-cost strategy while the higher of the expenses, the greater the emphasis on a differentiation strategy. 


\subsubsection{Firm performance}

Firm performance was measured using ROA, net profit margin, and employee satisfaction. ROA is calculated as net income divided by total firm assets and is commonly used as a measure of profitability in organization as argued by Zajac et al. (2000). As a performance indicator, the higher the net profit margin, the more effectively the firm is converting revenue to profit or the more pricing flexibility a firm may have in its operations or the greater cost control. It is calculated as net profit divided by total sales (total revenue). Comparing profit with sales volume was useful in determining whether the marketing research firms were converting assets and total revenue to profit efficiently.

Norton and Kaplan (1992), Kaplan (2010) and Becker et al. (2001) argue that satisfaction should also be used to measure performance. In this study, TMT satisfaction is used to measure performance as a reflection of TMT (Hambrick and Mason, 1984). Becker et al. (2001) suggest that employee satisfaction could be measured using employee motivation factors, such as absenteeism, employee turnover, training, and other employee benefits. Price (1977) defined turnover as the ratio of the number organizational members who have left during the period being considered divided by the average number of people in that organization during the period. Employee's turnover includes both voluntary and involuntary leaving employees (Sandra, 2011). Retired employees are excluded from the calculation, as employees whose fixed-term contracts expired. However, the data for TMT absenteeism rate, TMT turnover and employee benefits were not adequately available in the MSRA firms. Consequently, the three variables were omitted from the analysis of this study. Therefore, TMT satisfaction in this study was measured by training and medical expenses.

\subsection{Structural Equation Model Specification}

The representation of the hypotheses of the study in the form of structural equation model is specification (Kline, 2011). Specification, in turn, is drawing a model diagram using a set of more or less standardized graphical symbols, but the model can alternatively described by a series of equations. This study presented only the equations. The structural equation model for this study has three equations. The first equation is for the structural model while the second and third equations are for the measurement models.

$$
\eta_{\mathrm{i}(\mathrm{m} \times 1)}=\mathrm{B}_{(\mathrm{m} \times \mathrm{m})} \eta_{\mathrm{i}(\mathrm{m} \times 1)}+\Gamma_{(\mathrm{m} \times \mathrm{n})} \varepsilon_{\mathrm{i}(\mathrm{n} \times 1)}+\mathrm{S}_{\mathrm{i}(\mathrm{m} \times 1)}
$$

Where $\eta$ is a $m \times 1$ vector of endogenous variables and where it is assumed that the $m \times 1$ vector $\subseteq$ of error terms has zero mean and covariance matrix $\psi$, and $\operatorname{cov}\left(\mathcal{\varepsilon}_{0},\right)$ is zero.

The measurement models for the $\mathrm{p}$ endogenous observed variables represented by the vector $\mathrm{y}$, and the exogenous observed variables constrained in the vector $\mathrm{x}$, relate the observed (manifest) variables to the underlying factors (latent variables) is equated respectively as follows;

$$
\mathrm{Y}_{\mathrm{i}(\mathrm{p} \times 1)}=\Lambda_{\mathrm{y}(\mathrm{p} \times \mathrm{m})} \eta_{\mathrm{i}(\mathrm{m} \times 1)}+\mathrm{C}_{\mathrm{i}(\mathrm{p} \times 1)}
$$

where $\mathrm{E}(\mathrm{C})=0, \operatorname{Cov}(\mathrm{C})=\Theta$

$$
\mathrm{X}_{(\mathrm{q} \times 1)}=\Lambda_{\mathrm{x}(\mathrm{q} \times \mathrm{n})} \varepsilon_{\mathrm{i}(\mathrm{n} \times 1)}+\mathrm{z}_{\mathrm{i}(\mathrm{q} \times 1)}
$$

\subsection{Structural Equation Model Estimation}

This section involves using SEM computer tools (in this study, AMOS 21 using maximum likelihood was used). This is because the data were normally distributed and there was linear relationship between the variables) to conduct the analysis. Several things take place at this step, such as model fit evaluation (which means to determine how well the model explains the data), interpretation of the parameter estimates and equivalent or near-equivalent models (Kline, 2011).

The statistical techniques for overall model fit tests for this study selected those indices which are insensitive to small sample size. These are adjusted chi-square, comparative fit index (CFI), incremental fit index (IFI), goodness of fit index (GFI), adjusted goodness of fit index (AGFI), Tucker Lewis index (TLI) and root mean square error approximation (RMSEA). Adjusted chi-square ( $\chi 2 / \mathrm{df}$ ) was developed by Wheaton, Muthen, Alwin, and Summers (1977) and its recommended range is from as high as 5 (Wheaton et al. (1977) to as low as 2 (Tabachnick \& Fidell, 2007). CFI, developed by Bentler (1990), performs well even when the sample size is small (Tabachnick \& Fidell, 2007). A cut-off criterion of CFI $\geq 0.90$ was initially advanced. However, recent studies have shown that a value greater than 0.95 is needed in order to ensure that misspecified models are not accepted (Hu \& Bentler, 1999). The thresholds of IFI, GFI 
and AGFI were found to be greater than 0.90 (Cooper et al., 20008). Furthermore, the threshold for RMSEA was found to be less than 0.08 .

Interpretation of the parameter estimates was done using unstandardized regression weights. This was because the standardized regression weights do not have their own standard errors rather they used the standard error of unstandardized regression weights. Hence, interpretation using standardized weight may lead to type I error or type II error. .

\section{Discussion and Empirical Results}

\subsection{Response Rate}

The sample for the study comprised a total of $216(24 \times 9)$ out of 125 top level executives from 15 marketing research firms in MSRA. A total of 80 questionnaires were filled and returned. However, 2 of the returned questionnaires were discarded for lack of completeness, rendering them unusable for this study. The balances of 78 questionnaires were used for the analysis, representing a response rate of 62.2\%. Cooper and Schindler (2003) suggest that a response rate exceeding $30 \%$ of the total sample size provides enough data to explain the characteristics of the research problem. Therefore, the response rate of $62.2 \%$ was considered adequate for the analysis and interpretation in this study. Besides, this study was conducted for 12 years from 2003 up to 2014 for 9 marketing research firms. The data were collected semiannually from each of the nine marketing research firms. The firms were TNS, SBO, IPSOS, Nielsen, infinite insight, Strategic research, Research solution, Millennium and GFK.

\subsection{Preliminary Analysis}

Preliminary analysis is the initial process that provides a platform for further analysis to address the research objectives understudy. Therefore, prior to application of SEM, the data were subjected to diagnostic analysis to ascertain the appropriateness of its underlying parametric characteristics for this statistical application. This entailed the parametric tests of diversity, normality and confirmatory factor analysis.

\subsubsection{TMT Diversities}

Diversity is the differences among the TMT members based on educational level, educational background, experience, age, and gender. The descriptive statistics that elaborates the outcome of diversity is presented in table 4.1. The descriptive statistics summarized quantitatively large amount of data to bring out the distinctive features of the demographic diversities in this study. The data was analyzed using the IBM SPSS 21 statistical software. Table 4.1 summarized the diversities among the TMT members. The diversities were analyzed using Blau's (1977) heterogeneity index and coefficient of variance. When this index approaches to one diversity is considered to be high diversity while when it approaches zero diversity is considered to be low. The results in the table revealed that the firms had low TMT demographic diversities. The low diversities imply that the TMT members were relatively homogenous in terms of educational level, educational background, experience, and age composition.

Table 4.1 TMT demographic diversity

\begin{tabular}{|c|c|c|c|}
\hline \multicolumn{4}{|c|}{ Descriptive Statistics } \\
\hline & & Statistic & Std. Error \\
\hline \multirow{9}{*}{$\stackrel{\oplus}{\text { 界 }}$} & Mean & 0.43375 & 0.01916 \\
\hline & Median & 0.42 & \\
\hline & Variance & 0.02 & \\
\hline & Std. Deviation & 0.01 & \\
\hline & Minimum & 0.10 & \\
\hline & Maximum & 0.75 & \\
\hline & Range & 0.65 & \\
\hline & Skewness & 0.012 & 0.472 \\
\hline & Kurtosis & 2.222 & 0.918 \\
\hline \multirow{6}{*}{$\stackrel{\oplus}{\stackrel{\oplus}{\mid I}}$} & Mean & 0.31475 & 0.017189 \\
\hline & Median & 0.314 & \\
\hline & Variance & 0.00014 & \\
\hline & Std. Deviation & 0.012 & \\
\hline & Minimum & 0.25 & \\
\hline & Maximum & 0.62 & \\
\hline
\end{tabular}




\begin{tabular}{|c|c|c|c|}
\hline & Range & 0.37 & \\
\hline & Skewness & 0.324 & 0.472 \\
\hline & Kurtosis & 1.927 & 0.918 \\
\hline & Mean & 0.56133 & 0.018856 \\
\hline & Median & 0.57 & \\
\hline & Variance & 0.009 & \\
\hline & Std. Deviation & 0.092373 & \\
\hline 齐 & Minimum & 0.418 & \\
\hline & Maximum & 0.625 & \\
\hline & Range & 0.207 & \\
\hline & Skewness & -0.368 & 0.472 \\
\hline & Kurtosis & 1.794 & 0.918 \\
\hline & Mean & 0.34833 & 0.024757 \\
\hline & Median & 0.35 & \\
\hline & Variance & 0.015 & \\
\hline & Std. Deviation & 0.121285 & \\
\hline 是 & Minimum & 0.10 & \\
\hline & Maximum & 0.55 & \\
\hline & Range & 0.40 & \\
\hline & Skewness & 0.775 & 0.572 \\
\hline & Kurtosis & 1.463 & 0.518 \\
\hline
\end{tabular}

Furthermore, the normality and confirmatory factor analysis tests for the demographic diversity, generic strategy and performance factors indicators' results are critically and scientifically discussed below respectively. This is because such tests are the fundamental assumption in parametric testing in SEM analysis.

4.2.2 Normality Test

The data of this study were analyzed using maximum likelihood estimates. Under the maximum likelihood estimates, the data have to be normally distributed. The normality of the data was based on the Shapiro-Wilk test. On the basis of this test, most of the $p$-values in table 4.2 were greater than 0.05 , implying that we could not reject the null hypothesis that the data were normally distributed in terms of skewness and kurtosis.

Table 4.2 Normality tests

\begin{tabular}{lrcc}
\hline & \multicolumn{3}{c}{ Shapiro-Wilk } \\
\cline { 2 - 4 } ELD & Statistic & Df & Sig. \\
EBD & .851 & 216 & .030 \\
EXD & .708 & 216 & .098 \\
AD & .539 & 216 & .240 \\
MTE & .667 & 216 & .176 \\
ADE & .813 & 216 & .052 \\
SPE & .781 & 216 & .079 \\
SSE & .718 & 216 & .083 \\
SI & .867 & 216 & .021 \\
TRE & .587 & 216 & .236 \\
ME & .597 & 216 & .230 \\
ROA & .560 & 216 & .203 \\
NPM & .638 & 216 & .145 \\
& .465 & 216 & .340 \\
\hline
\end{tabular}




\subsubsection{Confirmatory Factor Analysis Test}

Given that the normality test is not enough for SEM, the data were further subjected for measurement models test using confirmatory factor analysis. Confirmatory Factor Analysis (CFA) is a special form of factor analysis, most commonly used in social research (Kline, 2011). It is a statistical technique used to test the hypothesis that the relationship between observed variables and their underlying latent constructs exists. However, it has to be started by testing whether the data fit to hypothesized measurement models or not. The measurement model fit tests are presented in table 4.3.

Table 4.3 Measurement model fit tests

CMIN

\begin{tabular}{|c|c|c|c|c|c|c|}
\hline Model & NPAR & CMIN & DF & $p$ & \multicolumn{2}{|c|}{ CMIN/DF } \\
\hline Default model & 25 & 62.180 & 30 & .000 & \multicolumn{2}{|c|}{2.073} \\
\hline Saturated model & 55 & .000 & 0 & & & \\
\hline Independence model & 10 & 549.813 & 45 & .000 & \multicolumn{2}{|c|}{12.218} \\
\hline \multicolumn{7}{|l|}{ RMR, GFI } \\
\hline Model & RMR & GFI & AGFI & & \multicolumn{2}{|c|}{ PGFI } \\
\hline Default model & .009 & .950 & .908 & & \multicolumn{2}{|c|}{.518} \\
\hline Saturated model & .000 & 1.000 & & & & \\
\hline Independence model & .048 & .657 & .581 & & \multicolumn{2}{|c|}{.537} \\
\hline \multicolumn{7}{|l|}{ Baseline Comparisons } \\
\hline \multirow[t]{2}{*}{ Model } & NFI & RFI & IFI & & TLI & $\mathrm{CFI}$ \\
\hline & Delta1 & rho1 & Delta2 & \multicolumn{3}{|c|}{ rho2 } \\
\hline Default model & .887 & .830 & .938 & & \multirow[t]{2}{*}{.904} & .936 \\
\hline Saturated model & 1.000 & & 1.000 & & & 1.000 \\
\hline Independence model & .000 & .000 & .000 & & .000 & .000 \\
\hline \multicolumn{7}{|l|}{ RMSEA } \\
\hline Model & RMSEA & LO 90 & HI 90 & & \multicolumn{2}{|c|}{ PCLOSE } \\
\hline Default model & .071 & .046 & .095 & & \multicolumn{2}{|c|}{.084} \\
\hline Independence model & .228 & .212 & .246 & & \multicolumn{2}{|c|}{.000} \\
\hline
\end{tabular}

The results in table 4.3 showed that the adjusted chi-square validated the data fit the model. This was because CMIN/DF was between 2 and 5, which is 2.073. The values of GFI, AGFI, IFI, TLI and CFI were also greater than the threshold value 0.90. Besides, RMSEA was less than its threshold value of 0.08 . Hence, overall, the data fitted the measurement models very well.

The results in tables 4.4 and 4.5 were all the statistically significant with p-values less than 0.05 , critical regions greater than the absolute value of $| \pm 1.96|$ and the multiple square correlations greater than 0.241 . Besides, the factor loadings were greater than 0.348 , implying that all the indicators significantly represented the latent variables. Hence, all the manifest variables were retained for SEM analysis.

Table 4.4 Regression weights for measurement model

\begin{tabular}{|c|c|c|c|c|c|c|c|}
\hline & & & Estimate & S.E. & C.R. & $p$ & Label \\
\hline $\mathrm{AD}$ & $<--$ & Demography & 1.000 & & & & \\
\hline EXD & $<--$ & Demography & .903 & .199 & 4.544 & $* * *$ & \\
\hline EBD & $<--$ & Demography & .466 & .131 & 3.548 & $* * *$ & \\
\hline ELD & $<--$ & Demography & -.348 & .123 & -2.839 & .005 & \\
\hline MTE & $<--$ & Strategy & 1.000 & & & & \\
\hline $\mathrm{ADE}$ & $<--$ & Strategy & -.405 & .091 & -4.464 & $* * *$ & \\
\hline SPE & $<--$ & Strategy & -.664 & .119 & -5.566 & *** & \\
\hline
\end{tabular}




\begin{tabular}{lllllll}
\hline TRE & $<---$ & Performance & 1.000 & & & \\
ROA & $<---$ & Performance & 1.628 & .296 & 5.509 & $* * *$ \\
NPM & $<---$ & Performance & 2.692 & .486 & 5.541 & $* * *$ \\
\hline
\end{tabular}

According to Hooper et al. (2008), if the square multiple correlation is greater than 0.20 , then the indicator significantly represent the construct. In this study, all the indicators significantly represented the constructs (see table 4.5). Hence, the entire manifest variables were retained for further analysis.

Table 4.5 Square Multiple Correlation

\begin{tabular}{lr}
\hline & Estimate \\
\hline NPM & .865 \\
ROA & .744 \\
TRE & .241 \\
SPE & .350 \\
ADE & .277 \\
MTE & .246 \\
ELD & .272 \\
EBD & .318 \\
EXD & .428 \\
AD & .404 \\
\hline
\end{tabular}

\subsection{Structural Model Fit Test}

The overall model fit was tested by adjusted chi-square, GFI, AGFI, RMSEA, NFI, IFI, TLI and CFI. The empirical results of the overall model fit were summarized in table 4.6. The results showed computed values of adjusted chi-square (2.029), GFI (0.950), AGFI (0.911), INF (0.939), TLI (0.908) and CFI (0.937) were all greater than the threshold value of 0.90 . Similarly, the computed value of RMSEA ( 0.069$)$ was less than the threshold value of 0.08 which is 0.069 . Therefore, the results validated that the data fit with the structural equation modeling.

Table 4.6 Structural equation model fit tests

CMIN

\begin{tabular}{|c|c|c|c|c|c|}
\hline Model & NPAR & CMIN & $\mathrm{DF}$ & $p$ & CMIN/DF \\
\hline Default model & 24 & 62.899 & 31 & .001 & 2.029 \\
\hline Saturated model & 55 & .000 & 0 & & \\
\hline Independence model & 10 & 549.813 & 45 & .000 & 12.218 \\
\hline \multicolumn{6}{|l|}{ RMR, GFI } \\
\hline Model & & RMR & GFI & AGFI & PGFI \\
\hline Default model & & .009 & .950 & .911 & .535 \\
\hline Saturated model & & .000 & 1.000 & & \\
\hline Independence model & & .048 & .657 & .581 & .537 \\
\hline \multicolumn{6}{|l|}{ Baseline Comparisons } \\
\hline \multirow[t]{2}{*}{ Model } & NFI & RFI & IFI & TLI & $\overline{\mathrm{CFI}}$ \\
\hline & Delta1 & rho1 & Delta2 & rho2 & \\
\hline Default model & .886 & .834 & .939 & .908 & .937 \\
\hline Saturated model & 1.000 & & 1.000 & & 1.000 \\
\hline Independence model & .000 & .000 & .000 & .000 & .000 \\
\hline \multicolumn{6}{|l|}{ RMSEA } \\
\hline Model & RMs & $\mathrm{LO}$ & & HI 90 & PCLOSE \\
\hline
\end{tabular}




\begin{tabular}{lcccc}
\hline Default model & .069 & .044 & .094 & .097 \\
Independence model & .228 & .212 & .246 & .000 \\
\hline
\end{tabular}

The square multiple correlations for the structural equation modeling in table 4.7 were greater than 0.20 . These validate that the variation in the endogenous variables are significantly explained by the exogenous variables. Moreover, this validates that the manifest variables explain the constructs well and the latent exogenous variables explain the latent endogenous variables significantly. Besides, the square multiple correlations showed that the data fit the SEM very well.

Table 4.8 Squared Multiple Correlations

\begin{tabular}{lr}
\hline & Estimate \\
\hline Strategy & .226 \\
Performance & .972 \\
NPM & .864 \\
ROA & .745 \\
TRE & .142 \\
SPE & .137 \\
ADE & .066 \\
MTE & .236 \\
ELD & .076 \\
EBD & .124 \\
EXD & .423 \\
AD & .406 \\
\hline
\end{tabular}

Finally, the impact of latent exogenous variables on latent endogenous variables was interpreted using unstandardized regression weights at $5 \%$ level of significance. The interpretation is the same as the factor loading in measurement model above except SEM mainly focuses on the relationship between constructs or factors.

\subsection{Effects of TMT Demographics Diversity on Generic Strategy}

The empirical results on relationship between TMTs demographic characteristics diversities on generic strategies are presented in table 4.8 . The results showed that strategic choice is strongly affected by the demographic diversities $(\mathrm{P}=$ 0.012). This supports the assumption of upper echelon theory. The null hypothesis $\left(\mathrm{H}_{01}\right)$ was not accepted because the firms that have low demographics diversities emphasized more on cost leadership strategy to achieve their objective. This could be attributed to team members having the same perception (homogenous team) may focus on specific issues, such as controlling costs. This was consistent with the findings of Hambrick and Mason (1984).

Table 4.8 Regression weights for structural equation modeling

\begin{tabular}{|c|c|c|c|c|c|c|c|}
\hline & & & Estimate & S.E. & C.R. & $\mathrm{P}$ & Label \\
\hline Strategy & $<--$ & Demography & -.869 & .374 & -2.324 & .012 & \\
\hline Performance & $<---$ & Strategy & .967 & .347 & 2.787 & .005 & \\
\hline $\mathrm{AD}$ & $<---$ & Demography & 1.000 & & & & \\
\hline EXD & $<--$ & Demography & .896 & .198 & 4.518 & $* * *$ & \\
\hline EBD & $<--$ & Demography & .478 & .131 & 3.639 & $* * *$ & \\
\hline ELD & $<---$ & Demography & -.357 & .123 & -2.895 & .004 & \\
\hline MTE & $<--$ & Strategy & 1.000 & & & & \\
\hline $\mathrm{ADE}$ & $<---$ & Strategy & -.388 & .089 & -4.358 & $* * *$ & \\
\hline SPE & $<---$ & Strategy & -.655 & .119 & -5.517 & $* * *$ & \\
\hline TRE & $<--$ & Performance & 1.000 & & & & \\
\hline ROA & $<--$ & Performance & 1.627 & .295 & 5.516 & $* * *$ & \\
\hline NPM & $<---$ & Performance & 2.687 & .484 & 5.548 & $* * *$ & \\
\hline
\end{tabular}




\subsection{Effects of Strategy on Performance}

The strategic choices of MSRA firms were identified and discussed under the sub-topics of demography and strategy (7.4). In this section, the influence of the strategic choices of firms on performance was discussed based on the results presented in table 4.8 .

The results showed that cost leadership strategy had positive significant impact on performance $(p=0.005)$. The findings of this study concur with the findings of Thomas and William (2004), Kumar et al. (1997), Power and Hahn (2004) and Dess and Devis (1984). Pure cost leadership strategy may be most effective when customers are sensitive to price and when strategic team members are more or less homogenous in composition. Likewise, in stable environments cost-leadership strategies may enhance performance better than differentiation. Besides, a differentiation strategy may be difficult to implant in a service industry because services are easily copied.

Since the environment had equal affect for all the research firms, the customers were sensitive to price (see table 4.9) and the TMT team were homogenous (see table 4.1), therefore, cost leadership strategy seems better than differentiation strategy. As a result, the firms that applied cost leadership strategy performed better. The finding failed to accept the null hypothesis $\left(\mathrm{H}_{02}\right)$ because cost leadership strategy has statistically significant effect on performance of marketing research firms (MRFs).

Table 4.9 Extent to which the customers are sensitive to price

\begin{tabular}{llcccc}
\hline & Frequency & Percent & Valid Percent & Cumulative Percent \\
\hline Valid & Very sensitive & 40 & 51.3 & 51.3 & 51.3 \\
& Sensitive & 31 & 39.7 & 39.7 & 91.0 \\
& Average & 6 & 7.7 & 7.7 & 98.7 \\
& Insensitive & 1 & 1.3 & 1.3 & 100.0 \\
& Total & 78 & 100.0 & 100.0 & \\
\hline
\end{tabular}

Furthermore, the empirical results revealed that cost leadership strategy might be favorable when the product-life cycle is at maturity and decline stages. Besides, it might be applicable if the firms are producing the same product and sales it in the same market (penetration strategy). This could also be explained by the general observation that the research firms are in Africa and their services are more or less identical. Moreover, the positive impact of cost leadership strategy on performance could be due to the firms' ability to develop specific set of competitive methods. In addition, the preference for the cost leadership strategy among the firms could be attributed to proper alignment of the functional strategies (strategic human resource management, strategic marketing management, strategic financial management, and strategic technological management among others) with business strategy as well as proper implementation of the strategy may bring a positive impact on performance.

\section{Conclusions}

The findings of this study supported the assumption of upper echelon theory and Carpenter (2002) where TMT attributes affect strategy and strategy affect performance. The low demographic diversities in the top level management were related to cost leadership strategy. Besides, cost leadership strategy showed a significant effect on performance. Therefore, automating the processes using sophisticated technology like online or virtual analysis and training may reduce the costs. Consequently, such strategy may help to increase the market share because the customers are price sensitive.

Additionally, cost leadership strategy is better in stable environment or when the strategic team members are homogenous. Besides, such strategy is favorable when the product-life cycle is at maturity and decline stages. Cost leadership strategy is also applicable if the firms are producing the same product and sales it in the same market. Furthermore, positive impact of cost leadership on performance is dependent on firm's ability to develop specific set of competitive methods (automation). In addition, the proper alignment of the functional strategies (strategic human resource management, strategic marketing management, strategic financial management, strategic technological management and others) with business strategy as well as proper implementation may matters most to affect performance positively.

\subsection{Policy Implication of the Study}

In order to fully use the potential of TMT diversities, organizations should distinguish between low, moderate, and high effects of diversity on performance. According to the general literature on team diversity, team leaders are likely to play an important role in this context. For example, by moderating team processes, team leaders should try to reduce the tendency for groupthink by facilitating external communication of team members. In addition, mentoring relationships between members of TMTs may help to enhance the wellbeing of the employees and firm performance. 
The government of Kenya is committed to have at least 30 percent presentation of any gender in public recruitments, promotions and appointment through gender mainstreaming in government policies, plans, budgets and programs. Besides, the literature argues that gender diverse organizations perform better than single gender organizations. A gender diverse workforce brings multiple source of information, variety of abilities to serve diverse customer base, and it attract and retain talented women. Moreover, women are opportunity experts, relationship specialist, constructive communicators, problem solvers, and multi-dimensional. However, the female proportion in the TMT members is inadequate. Hence, the MSRA firms should incorporate gender diversity to further enhance their performance.

The marketing research firms are emphasizing on cost leadership strategy. Hence, the marketing research firms need to focus more on automaton processes to apply cost leadership strategy more effectively and efficiently using sophisticated technology like online data collection, analysis and training. This will minimize one of the major costs in MSRA firms, namely, transportation costs. Besides, it enhances efficiency of service delivery to the customers.

Furthermore, the advantages of homogeneity accruing from our findings may only be applicable for a short run. Besides, the managers need to understand that Kenyan marketing research firms are still in the growth stage. As a result, in the long run firms need to be prepared to increase diversity in TMT in order to compete and sustain in the international market because heterogeneity paves ways for greater creativity, innovativeness and high performance. Therefore, the shareholders or board of directors need to be concerned with the dangerous practice known as 'groupthink' especially when homogeneity exists in TMTs. Undoubtedly, in the presence of education, experience and age diversities in the workforce, companies should consider heterogeneity in their teams at strategic level for better performance via creativity, innovativeness and quality decision making. Last but not least, power distribution among the TMT members should be considered for further research.

\section{Reference}

Allen, R. S., \& Helms, M. M. (2006). Linking strategic practices and organizational performance to Porter's generic strategies. Business Process Management, 12(4), 433-454. http://dx.doi.org/10.1108/14637150610678069

Allison, P. (1978). Measures of inequality. American Sociological Review, 43, 865-880. http://dx.doi.org/10.2307/2094626

Amy, C. D., Michael, A. R., \& Michael, D. W. (2003). A dynamic model of top management team effectiveness: Managing unstructured task streams. The Leadership Quarterly, 14, 297-325. http://dx.doi.org/10.1016/S1048-9843(03)00021-3

Arpita, A. (2014). The role of the upper echelon in the value chain management. Competitiveness Review, 24(3), 240-255. http://dx.doi.org/10.1108/CR-05-2013-0049

Auden, W. C., Shackman, J. D., \& Onken, M. H. (2006). Top management team, international risk management factor and firm performance. Team Performance Measurement, 12(7), 209-224. http://dx.doi.org/10.1108/13527590610711778

Becker, B. E., Huselid, M. A., \& Ulrish, D. (2001). The human resource scorecard: Linking people, strategy, and performance. Boston, MA: Harvard Business School Press.

Bentler, P. M. (1990). Comparative fit indexes in structural models. Psychological Bulletin, 107(2), 238-246. http://dx.doi.org/10.1037/0033-2909.107.2.238

Bharadwaj, S. G., Varadarajan, P. R., \& Fahy, J. (1993). Sustainable competitive advantage in service industries: a conceptual model and research propositions. Journal of Marketing, 57, 83-99. http://dx.doi.org/10.2307/1252221

Blau, P. M. (1977). Inequality and Heterogeneity: A primitive theory of social structure. The Free Press, New York.

Bollen, K. A. (1989). Structural equations with latent variable. New York, Wiley. http://dx.doi.org/10.1002/9781118619179

Boselie, P. (2010). Strategic human resource management: A balanced approach. London, McGraw-Hill Companies.

Camelo, M. C., Hernandez, A. B., \& Valle, R. (2005). The relationship between top management teams and innovative capacity in campanies. Journal of Management Development, 24, 683-706. http://dx.doi.org/10.1108/02621710510613726

Carpenter, M. A. (2002). The implications of strategy and social context for the relationship between top management team heterogeneity and firm performance. Strategic Management Journal, 23, 275-284. http://dx.doi.org/10.1002/smj.226

Chen, Y., Ge, Y., \& Song, Z. (2010). Power perspective: A new framework for top management theory. iBusiness, 2 , 274-281. doi:10.4236/ib.2010.23035 Published Online September 2010. http://dx.doi.org/10.4236/ib.2010.23035 
Daniel, K., Tanja, C. P., \& Utz, S. (2007). Effect of top management team characteristics on strategic decision making. Management decision, 45, 942-967. http://dx.doi.org/10.1108/00251740710762017

Davidson, R., \& Billington, C. (2010). Using knowledge brokering to improve business process. Mckinsey Wuarterly, 2, $110-112$.

Dess, G. G., \& Davis, P. S. (1984). Generic strategies as determinants of strategic group membership and organizational performance. Academy of Management Journal, 27(3), 467-488. http://dx.doi.org/10.2307/256040

Dimitrios, K., Vassilios, Z., Maria, A., \& Jaideep M. (2008). Top management team and corporate performance: A study of Greek firms. Team Performance Management, 14(7), 340-363.

Dushyantha, K. (2008). Electronic commerce strategies, generic strategies and firm performance: A study of small and medium enterprises in Aichi, Japan. Japanese Journal of Administrative Science, 21(1), 27-46. http://dx.doi.org/10.5651/jaas.21.27

Finkelstein, S. (1992). Power in top management teams: Dimensions, measurements and validation. Academic of Management Journal, 35, 505-538. http://dx.doi.org/10.2307/256485

Finkelstein, S., \& Hambrick, D. C. (1990). Top management team tenure and organizational outcomes. The moderating role of managerial discretion. Administrative Science Quarterly, 35, 484-503. http://dx.doi.org/10.2307/2393314

Geletkanycz, M. A., \& Black, S. S. (2001). Bound by the past: Experience-based effects on commitment to the status quo. Journal of Management, 27, 3-21. http://dx.doi.org/10.1177/014920630102700103

Goll, I., Sambharya, R. B., \& Tucci, L. A. (2001). Top management team composition, corporate ideology and firm performance. Management International Review, 41(2), 109-129

Hambrick, C. D. (2007). Upper echelons theory: an update. Academy of management Review, 32, 334-343. http://dx.doi.org/10.5465/AMR.2007.24345254

Hambrick, D. C., \& Mason, P. A. (1984). Upper echelons: The organization as a reflection of its top managers. Academy of Management review, 9, 196-200.

Heng-Yih, L., \& Chia-Wen, H. (2011). Antecedents and consequences of corporate diversification: A dynamic capabilities perspective. Management Decision, 49(9), 1510-1534. http://dx.doi.org/10.1108/00251741111173961

Herrmann, P., \& Datta, D. L. (2005). Relationships between top management team characteristics and international diversification: An empirical investigation. British Journal of Management, 16, 60-78. http://dx.doi.org/10.1111/j.1467-8551.2005.00429.x

Hitt, M., \& Tyler, B. (1991). Strategic decision model: Integrating different perspectives. Strategic Management Journal, 12, 327-352. http://dx.doi.org/10.1002/smj.4250120502

Hlavacka, S., Bacharova, L., Rusnakova, V., \& Wagner, R. (2001). Performance implications of porter's generic strategies in Slovak hospitals. Journals of Management in Medicine, 15(1), 44-66. http://dx.doi.org/10.1108/02689230110386489

Hooper, D., Coughlan, J., \& Mullen, M. (2008). Structural equation modeling: Guidelines for determining model fit. Electronic Journal of Business Research Methods, 1(6), 53-60.

Hu, L. T., \& Bentler, P. M. (1999). Cutoff criteria for fit indexes in covariance structure analysis: Conventional criteria versus new alternatives. Structural Equation Modeling, 6(1), 1-55. http://dx.doi.org/10.1080/10705519909540118

Irene, G., Nancy, B. J., \& Abdul, A. R. (2008). Top management team demographic characteristics, business strategy, and firm performance in the US airline industry: The role of managerial discretion. Management Decision, 46, 201-222. http://dx.doi.org/10.1108/00251740810854122

Kakabadse, N. K., Kakabadse, A. P., \& Barrat, R. (2006). Chairman and chief executive officer: That sacred and secret relationship. Journal of Management Development, 25(2), 134-150. http://dx.doi.org/10.1108/02621710610645126

Kaplan, R. S. (2010). Conceptual foundations of the balanced scorecard: working Paper. Harvard Business School Press. http://dx.doi.org/10.2139/ssrn.1562586

Kaplan, R. S., \& Norton, D. P. (1992). The balanced scorecard: Measures that drive performance. Harvard Business Review, 71-79.

Kim, E., Nam, D., \& Stimpert, J. (2004). The applicability of Porter's generic strategies in the digital age: Assumptions, conjectures, and suggestions. Journal of Management, 30(5), 569-589. http://dx.doi.org/10.1016/j.jm.2003.12.001

Kline, R. B. (2011). Principles and practice of structural equation modeling. 3er edition, New York, the Guilford Press. 
Kroll, M., Walters, B. A., \& Le Son, A. (2007). The impact of board composition and top management team ownership structure on post-IPO performance in young entrepreneurial firm. Academy of Management Journal, 50(5), 1198-1216. http://dx.doi.org/10.2307/20159920

Kumar, K., Subramanian, R., \& Yauger, C. (1997). Pure versus hybrid: Performance implications of porter's generic strategies. Health Care Management Review, 22(4), 47-60. http://dx.doi.org/10.1097/00004010-199710000-00008

Margarita, I. (2008). The balanced scorecard method: From theory to practice. International Economics, 1(3), 18-28

Marimuthu, M., \& Kolandaisamy, I. (2009). Demographic diversity in top level management and its implications on firm financial performance: An empirical discussion. International Journal of Business and Management, 4(6), 176-185. http://dx.doi.org/10.5539/ijbm.v4n6p176

Mason, A. C., \& Gregory, P. R. (2006). Constructs and construct measurement in upper echelons research, in David J. Kentchen, Donald D. Bergh (ed), 3, 17-35.

Michael, A. A. (2010). Top team composition and corporate turnaround under environmental stability and turbulence. Leadership and Organizational Development Journal, $196-212$. http://dx.doi.org/10.1108/01437731011039325

Miller, D. (1992). The generic strategy trap. Journal of Business Strategy, 13(1), 37-42. http://dx.doi.org/10.1108/eb039467

Nandakumar, M. K., Abby, G., \& Nicholas, O. (2010). Business level strategy and performance: The moderating effects of environment and structure. Management Decision, 48(6), 907-939. http://dx.doi.org/10.1108/00251741011053460

Nayyar, P. R. (1993). On the measurement of competitive strategy: Evidence from a large multiproduct US firm. Academy of Management Journal, 36(6), 1652-1669. http://dx.doi.org/10.2307/256825

Nielsen, S. (2010). Top management team diversity: A review of theories and methodologies. International Journal of Management Reviews, 12(3), 301-316.

Pearson, J. A., \& Richard, B. R. (2009). Strategic management: Formulation, implementation and control. $11^{\text {th }}$ edition. Boston, McGraw-Hill, Higher education.

Porter, M. E. (1980). Competitive strategy. Free press, New York, NY.

Powers, T. L., \& Hahn, W. (2004). Critical competitive methods, generic strategies, and firm performance. The International Journal of Bank Marketing, 22(1), 43-64. http://dx.doi.org/10.1108/02652320410514924

Price, J. L. (1977). The study of turnover. Iowa State University Press, Ames, IA.

Rajiv D. B., Raj, M., \& Arindam, T. (2014). Does a differentiation strategy lead to more sustainable financial performance than a cost leadership strategy? Management Decision, 52(5), 872-896. http://dx.doi.org/10.1108/MD-05-2013-0282

Sandra, G. (2011). Diversity and employee turnover in the Dutch public sector: Does diversity management make a difference? International Journal of Public Sector Management, 24(6), 594-612. http://dx.doi.org/10.1108/09513551111163675

Simeon, R. (2001). Top team characteristics and business strategies of Japanese firms. Corporate governance, MCB University Press, 4-12. http://dx.doi.org/10.1108/14720700110394344

Smith, W. K., \& Tushman, M. L. (2005). Managing strategic contraptions: A top management model for managing innovation streams. Organization Science, 16(5), 522-536. http://dx.doi.org/10.1287/orsc.1050.0134

Stephen, P. R., Timothy, A. J., \& Neharika, V. (2012). Organizational Behavior. $14^{\text {th }}$ edition, Pearson Education, Delhi.

Sujith, N., Arsalan, N., Miguel, P., \& Felipe, R. (2012). Impact of knowledge brokering on performance heterogeneity among business models. Management Decision, 50(9), 1649-1660. http://dx.doi.org/10.1108/00251741211266732

Tabachnick, B. G., \& Fidell, L. S. (2007). Using multivariate statistics. $5^{\text {th }}$ edition. New York: Allyn and Bacon.

Thomas L. P., \& William, H. (2004). Critical competitive methods, generic strategies, and firm performance. International Journal of Bank Marketing, 22(22), 43-64.

Tihanyi, L., Ellstrand, S. E., Daily, C. M., \& Dalton, D. R. (2000). Composition of the top management team and firm international diversification. Journal of Management, 23, 1157-1177. http://dx.doi.org/10.1177/014920630002600605

Wheaton, B., Muthen, B., Alwin, D. F., \& Summers, G. (1977). Assessing reliability and stability in panel models. 
Sociological Methodology, 1 (8), 84-136. http://dx.doi.org/10.2307/270754

Wiersema, M., \& Bantel, K. A. (1992). Top management team demography and corporate strategic change. Academy of Management Journal, 35, 91-121. http://dx.doi.org/10.2307/256474

Young, M. (1999). Market structure analysis: A foundation for developing and assessing bank strategy. The International Journal of Bank Marketing, 17(1), 20-25. http://dx.doi.org/10.1108/02652329910254019

Zajac, E. J., Kraatz, M. S., \& Bresser, R. F. (2000). Modeling the dynamics of strategic fit: A formative approach to strategic change. Strategic Management Journal, 21(4), 429-54.

http://dx.doi.org/10.1002/(SICI)1097-0266(200004)21:4<429::AID-SMJ81>3.0.CO;2-\#

Zikmund, G. W., Babin, J. B., Jon, C. C., \& Mitch, G. (2010). Business research methods. $8^{\text {th }}$ edition. Austria, South-Western Cengage learning.

This work is licensed under a Creative Commons Attribution 3.0 License. 